\title{
Promoting Tourists' Destinations in Greece with Social Media: The Case of Kimolos Island
}

\author{
Submitted 14/12/20, $1^{\text {st }}$ revision 28/01/21, $2^{\text {nd }}$ revision 19/02/21, accepted 20/03/21
Mylona Ifigeneia ${ }^{1}$, Amanatidis Dimitrios $^{2}$, Stavrianea Aikaterini ${ }^{3}$, Kamenidou Irene (Eirini) ${ }^{4}$, Mamalis Spyridon ${ }^{5}$

\begin{abstract}
:
Purpose: The paper examines how social media presents Kimolos, a small Cycladic island in the Aegean Sea, to future travelers. This research provides valuable information regarding the actions taken by Kimolos and the local enterprises' actions in promoting the island and the local products and attracting tourists using social media.

Methodology/Approach/Design: Quantitative research and qualitative methods were used for the collection of data. Data were collected during the period between May and June 2018. Findings: Enterprises in Kimolos have realized the potential to use the world wide web and social media to promote their services. The municipality of Kimolos, on the other hand, do not use social media at the time that the research took place, but it is planning to use it in the future.

Practical implications: This research seeks to show tourism professionals the use of social networks and encourage them to use them.

Originality/Value: There is limited research in Greece about promoting services and products through social media in small Greek islands.
\end{abstract}

Keywords: Social media, communications, public relations, Greece, tourism.

Paper Type: Research study.

\footnotetext{
${ }^{1}$ Department of Management Science and Technology, International Hellenic University, Kavala, Greece, e-mail: imylona@mst.ihu.gr

${ }^{2}$ Faculty off Pure Sciences and Technology, Hellenic Open University, Greece, e-mail: amanatidis.dimitrios@ac.eap.gr

${ }^{3}$ Department of Communications and Mass Media, National and Kapodistrian University of Athens, Athens, Greece, e-mail: aikstavria@media.uoa.gr

${ }^{4}$ Department of Management Science and Technology, International Hellenic University, Kavala, Greece, e-mail: rkam@mst.ihu.gr

${ }^{5}$ Department of Management Science and Technology, International Hellenic University, Kavala, Greece, e-mail: mamalis@mst.ihu.gr
} 


\section{Introduction}

Tourism seems to be an important industry for the Greek economy as it is a vital pillar for household income and employment. This holds especially for regions such as the Aegean islands and remote mainland Greece that cannot depend on alternative income sources (Belias et al., 2017). Social media have changed how society consumes and contributes to information generation (Hays et al., 2013). Thus, there is a need for Greek business executives to understand their importance and exploit them for the promotion of their products and services in the tourist industry.

Social media have been a part of our everyday activities for quite a few years now. This umbrella term includes applications and services that can be further categorized into social networking sites, blogs and microblogging services, image and video sharing platforms, wikis, synchronous text, and video messaging, and more. A definition of the term given by Kaplan and Haenlein (2010: 61) states that "Social Media is a group of Internet-based applications that build on the ideological and technological foundations of Web 2.0 that allow the creation and exchange of User Generated Content." This definition emphasizes a user-centric web and is following studies, such as, e.g., Thevenot (2007), which shows that as social media popularity increases, users acquire more power while, at the same time, the authority of marketers and institutions recesses.

Social media users can generate and interact with either private, semi-private or public content through their friends' networks, their followers, or other social media users (Alhabash et al., 2017). In this way, marketers of touristic destinations can contact visitors more economically and more efficiently than what could be achieved through traditional communication tools (Kaplan and Haenlein, 2010). As social media have altered the way society consumes and contributes to information generation (Hays et al., 2013), there is a need for business executives in the Greek territory to understand its importance and utilize them for the promotion of their products and for providing information to those who are interested. A social network encapsulates, by definition, the notion of all people in a shared relationship. However, as Huberman (2008) claims, people only interact with very few of their network associates.

The paper argues that social media may be used in tourist destinations for promoting services. Municipalities and companies in small places in Greece seem to understand the importance of social media usage as it is an economical and convenient way to attract tourists. Motivated by the fact that there is limited research in Greece about the promotion of services and products through social media in small Greek islands, this work tries to fill this gap by examining social media usage by companies in Kimolos, a small island in the Aegean Sea. The study's target is to identify if the local businessmen in Kimolos use the internet and social media as a new way of promoting their services. Moreover, it explores the use of the internet and social media by the local authorities for advertising and promoting the services and the beauties of the island to the tourists. The paper tries to identify if tourists submit to social media their 
reviews about the quality of restaurants and hotels' services. The study focuses on Facebook, TripAdvisor, and Instagram.

This work focuses on the application of social media in the tourism sector. Indeed, concerning tourism, marketers, and institutions have no longer supreme control over their destination or product image, as this is to a large degree shaped by related usergenerated content, which may include reviews, recommendations, ratings and rankings, comments, etc. of services offered in a specific touristic destination.

\section{Social Media and Tourist Destinations}

As stated previously, Web 2.0 and social media have dramatically changed how consumers plan their trip as they enable them to interact and offer peer-to-peer advice (Buhalis and Law, 2008). Social media's influence on tourism is rapidly growing as, in many cases, social media is becoming a primary information source for travellers (Xiang and Gretzel, 2010) and provide new ways of choosing a holiday destination (Karyotakis, 2018). Social media equip users with a collection of various interactivity options. These options range from a simple chat or email conversation to blogs and discussion groups (Miguens et al., 2008). Facebook is one of the most popular social media platforms and is utilized by both the demand and the tourism industry's supply sides (Önder et al., 2019 and Alghizzawi et al., 2019). Hanan and Petit (2014, 471) describe Instagram as one of the most frequently used image-based social media applications in the world and as "a trendy tool in digital tourism where snapshots and comments can be shared all across one's social media channels within seconds, and anybody could be in expressing their likes or dislikes towards a place of interest." TripAdvisor provides countless reviews and feedback on accommodation, restaurants, experiences, airline tickets, and cruises and can influence many travellers (Seok et al., 2020).

There is still a question of whether travellers use social media platforms and review sites for seeking information. On the one hand, social media are not used by all the travellers that use the internet for travel planning but by an important number of travellers (Yoo, 2016). On the other hand, one cannot underestimate the increasing importance of networks formed by social media, sites for online reviews and opinions, and booking services concerning the pre-booking information search and the final booking process itself (Dieck et al., 2018).

Celebrities could also influence their comments on social media. Marketers could consider inviting celebrities to be the destination endorsers by sharing their experiences (Xu and Pratt, 2018) and travel influencers that produce blogs and social media content reflecting their personal brands, individual ethics, and audience relationships (Stoldt et al., 2019). The development of a positive or negative attitude can happen naturally while users engage in their daily online activities, including social media participation (Chatzigeorgiou and Christou, 2019). 
In some cases, local communities and authorities understand the need for using social media to promote their places as tourist destinations and provide all the relevant information required to future tourists. In fact, the perceived level of influence from social media is in strong correlation with changes made in holiday plans before final decisions (John et al., 2012). Social media is a popular source of information among tourists when searching for new inspirational destinations (Dickinger and Lalicic, 2015). A good example mentioned by Bodnar (2010) is that in a single day, more than three million photos are uploaded to Flickr, five million tweets are posted on Twitter, and one million posts appear on other blog sites.

Leung, Law, Van Hoof, and Buhalis (2013), highlight the strategic importance of social media for the successful promotion of tourism in terms of competitiveness. The authors explore leveraging of social media for the ten most frequently visited countries in the world. They point out that many tourists are still unaware of this relatively new technology, which does not constitute a vital necessity for their marketing strategies. Another work from the same year, (Munar and Jacobsen, 2013) studies Scandinavian tourists' perceptions in Mallorca, differentiating between Web 1.0 and Web 2.0 information sources. The authors found high motivation for sharing tourism experiences and knowledge on sites with a high richness of social cues. A year later, in their subsequent study, Munar and Jacobsen (2014) found out that Scandinavian social network sites such as Facebook were the most popular among the Scandinavian Mallorca tourists, who liked to share their visual experiences on social media.

According to Kim, Lee, Shin, and Yang (2017), Chinese tourists have used social media as an influential source for acquiring touristic information of the Sina Weibo destination. In their work, the role of content and non-content cues of tourism information quality in social media was investigated. Another research examines if travellers use social media before traveling and visiting their destination. In the same year (2017), Hassan explores social media's employment for marketing in Finland as a tourist destination focused on Spanish tourists. The results showed that there are segments that can be reached easily with the use of social media.

Çelik, Yüzbaşığlu, and Topsakal (2017) in their research study the content of photos shared from Turkey's official social media account, Home Turkey. In total, 300 photographs were reviewed, and most of the shares have been made on tulips and hand-woven carpets.

In a more recent study, Chu and Luckanavanich (2018) explore social media usage by Thai people in choosing travel destinations. They claimed that Thai people do use social networks to look for information about their future travels. The most popular media are Facebook and YouTube. 


\begin{tabular}{|c|c|}
\hline Author & $\begin{array}{l}\text { Use of social media for promotion of tourist } \\
\text { destinations }\end{array}$ \\
\hline Leung, Law, Van Hoof, and Buhalis (2013) & $\begin{array}{l}\text { importance of social media for tourism } \\
\text { competitiveness }\end{array}$ \\
\hline Munar, and Jacobsen (2013-4) & use of social media in Scandinavian countries \\
\hline Kim, Lee, Shin, Yang (2017) & $\begin{array}{l}\text { social media as an influential source of } \\
\text { information for Chinese tourists }\end{array}$ \\
\hline $\begin{array}{l}\text { Çelik, P., Yüzbaşıoğlu, N., and Topsakal, Y. } \\
\text { (2017) }\end{array}$ & use of social media in Turkey \\
\hline Chu and Luckanavanich (2018) & use of social media by Thai people \\
\hline
\end{tabular}

Source: Own creation.

\section{Kimolos Island}

Kimolos, or Argentziera, as the Franks "named" it in the 13th century, is a small island located in the Central Aegean Sea. It is part of the South Aegean Volcanic Arc (Fragoulis, 1997). Kimolos is close to the northwest of the larger Milos Island, separated by a $1 \mathrm{~km}$-wide channel. The population is 910 residents, according to the 2011 census. The island has a total area of 36 square kilometers. The highest point is mount Paleokastro, at 364 meters (1,194 feet). The only town is Chorio, located on a hill on the west of the island. There are also smaller settlements such as Psathi (port), Goupa, Kara, Prasa, Aliki, and Bonatsa near the sea and offer themselves for a swim. Despite its small size, Kimolos has a great number of churches. These post-Byzantine churches, along with the Medieval Castle, the Archaeological and the Folklore Museums places of interest and popular tourist attractions. Nice and clean beaches can be found in Kimolos. The most famous ones are Bonatsa, Prassa, Monastiria, Rema, Klima and Mavrospillia (Kimolos, 2018 Most beaches can be reached by car; some can be reached only by boat.

On the northwestern part of Kimolos, there is a huge stone mushroom, "Skiadi," as the island people call it. Also, an impressive monument can be found in the middle of a barren plateau with an excellent view. The tourist comes upon beaches, such as Ellinika, Mavrospilia, Athinia, and faces a large part of Milos (Kimolos, 2018.). Travelers can only reach 'Skiadi' by walking a long distance of about an hour.

The most popular local foods of Kimolos include "ladenia," a delicacy made of dough, fresh tomato, onion, and olive oil, "tirenia" (cheese pie with local cheese and a special kind of dough), "elenia" (bread with local olives), which can be found at the bakeries of the island.

A few years ago, Kimolos was not a famous destination for tourists as there were not many hotels on the island, and tourism development was limited. Over the last decade, there has been a rise in the island's touristic development, and the number of visitors to it has increased significantly. Small hotels have been built, and more restaurants have opened. 


\section{Methodology of the Study}

As mentioned above, this study aims to examine how the municipality of Kimolos and the local enterprises use the media to promote the island and its local products to tourists. Towards this aim, we exploit methodological triangulation, which refers to "the use of more than one method for gathering data" (Denzin and Lincoln, 1998), i.e., both qualitative and quantitative methods for data collection have been utilized. Qualitative research is designed to exhibit the target audience's behavioral variations and the perceptions that fuel it concerning topics or issues. Qualitative research employs in-depth studies of small groups of people to enable hypotheses posing. The results of qualitative research are descriptive, in contrast to quantitative research, where results are predictive. Quantitative research aims to provide an objective method for studying scientific interest phenomena (Benoit and Holbert, 2008).

Quantitative content analysis is used for the study. "Quantitative content analysis is the systematic and replicable examination of symbols of communication, which have been assigned numeric values according to valid measurement rules, and the analysis of relationships involving those values using statistical methods, in order to describe the communication, draw inferences about its meaning, or infer from the communication to its context, both of production and consumption" (Riffe et al., 1998). A list of all Kimolos hotels and restaurants was extracted from the official Kimolos municipality tourist guide in June of 2018. There is a total of 32 accommodation properties and 34 restaurants and bars. The guide also had information on email addresses, and web pages, if applicable. Following this first step, we searched for information on each company and whether they had a Facebook page, an Instagram profile, and if they appeared on TripAdvisor. Concerning the email addresses, we discriminated between corporate or web pages and whether it was based on a private domain or listed on a directory. For Facebook, Instagram, and TripAdvisor, additional data was extracted to indicate the entries with the stronger and more active presence and indicate the degree of interaction with their audience.

The qualitative research data was supplemented by an interview with the mayor of Kimolos to investigate the use of the internet and social media by the island's municipality. The researchers analysed the official web page of the municipality (Kimolos, 2018) as well. The face-to-face interview took place in May 2018.

\section{Municipality's Actions: The Interview Analysis}

According to the mayor of Kimolos, the municipality has created an official web site (Kimolos, 2018) that is well structured, with much information and multimedia content, including information on accessing the island, the sights of Kimolos, local products, the beaches of Kimolos and Polyaegos, churches and archeological sites. There is also a naval interactive sea map where you can see the ships sailing around Kimolos in real-time. There is a tourism section with a business directory for accommodation, food, entertainment, travel agencies, and other services. There are also maps of the island hiking routes. According to the mayor, the Municipality of 
Kimolos is updated every time the Municipality must make an announcement or inform citizens and tourists about its activities. The Municipality of Kimolos employs a professional administrator for the site.

The mayor of Kimolos also claimed that tourists use email to communicate with the municipality and get an answer quite shortly. Tourists can communicate with the municipality in Greek, English, French and Italian. Even though the island's municipality uses email for communication with tourists, it does not, however, use Viber and messenger and does not have an official profile on Facebook, Instagram, and Tripadvisor; they are planning though to create social media profiles shortly. Another important outcome from the interview was that non-official bodies promote the island, e.g., the visitors of the island and the Kimolians. A volunteer group, Kimolistes, is active on social media platforms and tries to promote the island and provide tourists with information.

\section{Quantitative Analysis Results-Statistics for Hotels and Restaurants in Kimolos}

In this part of the paper, the results of the quantitative research analysis are presented. A total of 32 hotels and 34 restaurants were extracted from the official Municipality of Kimolos Tourist Guide.

Figure 1. Hotel analysis

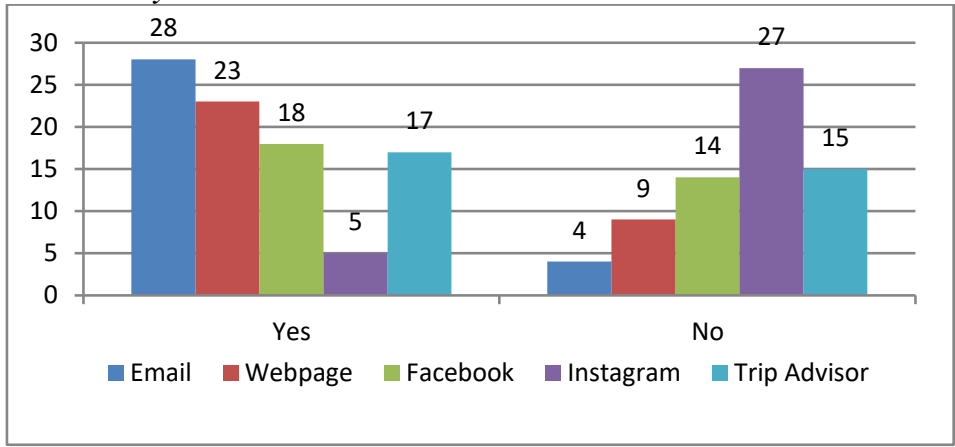

Source: Own creation.

Figure 1 displays the number of hotels versus five media categories, namely email, webpage, Facebook, Instagram, and Trip Advisor. Most hotels use email to communicate with their future clients. Also, more than half of the hotels have a website and a Facebook account. Out of the 28 hotels with email addresses, 12 have webmail, whereas 16 have a corporate associated with their registered email (Figure 2).

In figure 3, the domain that the hotels have is depicted: most of the hotels have their own registered domain for their webpage and only four of them use a tourist directory like gokimolos. 
Figure 2. Hotels' e-mail type

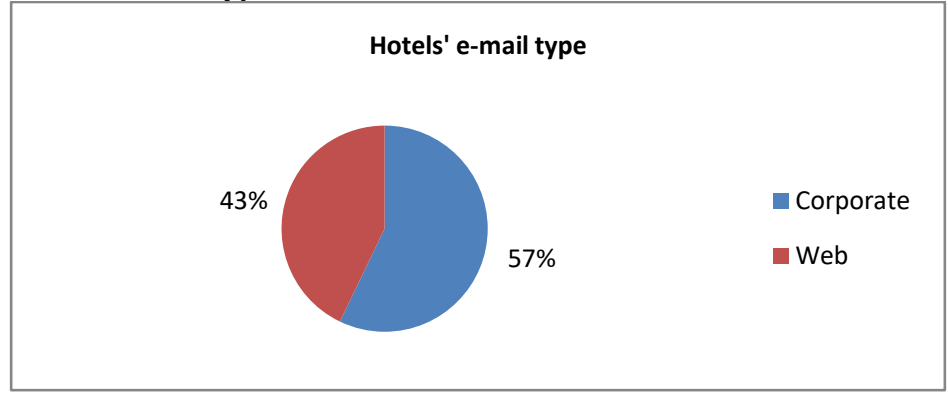

Source: Own creation.

Figure 3. Hotels' webpage type

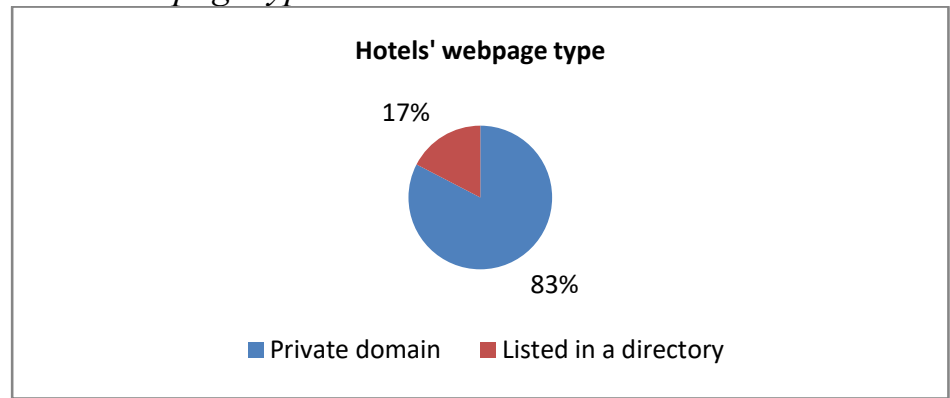

Source: Own creation.

In Table 2, it can be observed that among the 18 Facebook pages, all 18 of them have a "Likes" score, 11 pages have posted comments, and 7 pages have reviewed and an associated rating. The number of likes sorts of Facebook pages. Clearly, Kimolia-GiStudios and Echinousa Katoikies surpass all other hotels in likes. The average number of likes is 454.5 , and the standard deviation is 500.5 indicating quite widespread. However, it is worth mentioning that the six hotels with the lowest likes' pages belong to the Aria Hotels Group, and their customers probably use the central Aria Hotels Group page for their likes, comments, and reviews. Although the reviews are not that many, the respective score is high.

Table 2. Hotels' Facebook pages

\begin{tabular}{|c|c|c|c|c|}
\hline Facebook Page & $\begin{array}{c}\text { FB } \\
\text { Likes }\end{array}$ & $\begin{array}{c}\text { FB } \\
\text { Comments }\end{array}$ & $\begin{array}{c}\text { FB } \\
\text { Reviews }\end{array}$ & $\begin{array}{c}\text { FB } \\
\text { Rating }\end{array}$ \\
\hline Kimolia-Gi-Studios & 1910 & Yes & 59 & 4.6 \\
\hline EchinousaKatoikies & 1429 & Yes & 61 & 4.8 \\
\hline sardis.kimolosrooms & 697 & Yes & & \\
\hline Bonatsa & 591 & Yes & 24 & 5 \\
\hline Kimolis & 560 & Yes & 28 & 5 \\
\hline Мıкро́-Парі́бı & 551 & & & \\
\hline OpalioApartmentsKimolos & 504 & Yes & 6 & 5 \\
\hline kimolos.tuffs & 445 & Yes & 22 & 4.9 \\
\hline Kimolos-Themonia-studios & 328 & Yes & & \\
\hline villamaria.kimolos & 327 & Yes & & \\
\hline PrezanisKonstantinos & 308 & Yes & 6 & 5 \\
\hline
\end{tabular}




\begin{tabular}{|l|r|l|l|l|}
\hline KimolosBlue (Aria Hotels) & 226 & & \\
\hline Argilily & 97 & Yes & \\
\hline BonatsaBeachHouse (Aria Hotels) & 64 & & \\
\hline PsathiBlue (Aria Hotels) & 63 & & \\
\hline AlikakiKimolos (Aria Hotels) & 61 & & \\
\hline MilakiKimolos (Aria Hotels) & 15 & & \\
\hline $\begin{array}{l}\text { windmill.kimolos (Aria Hotels - } \\
\text { dormant) }\end{array}$ & 5 & & \\
\hline
\end{tabular}

Source: Own creation.

Concerning the use of Instagram, only five hotels have Instagram accounts, shown in table 3, sorted by their number of followers. Again, it can be observed that the Aria Hotels Properties (Milaki, Windmill) probably use the central Instagram account for their posts and receive reviews, etc., there as well.

Table 3. Hotels' Instagram accounts

\begin{tabular}{|l|r|r|r|}
\hline \multicolumn{1}{|c|}{ Name } & Posts & Followers & \multicolumn{1}{|c|}{ Following } \\
\hline Kimoliagistudios & 29 & 495 & 807 \\
\hline Mikroparisi & 13 & 237 & 13 \\
\hline $\begin{array}{l}\text { Prezanis Rooms-Cafe- } \\
\text { Restaurant }\end{array}$ & 122 & 186 & 401 \\
\hline Windmill & 12 & & \\
\hline Milaki & 1 & & \\
\hline
\end{tabular}

\section{Source: Own creation.}

Of the 17 properties that appear in TripAdvisor (sorted by their rating), the largest number have a rating which is 4 or higher. It is significant to mention at this point that TripAdvisor's rating system, although not fully disclosed, considers 3 key factors; the number of reviews, how favourable the reviews are, and how old or recent the reviews are.

Table 4. Hotels appearing in Tripadvisor

\begin{tabular}{|l|r|r|}
\hline \multicolumn{1}{|c|}{ Name } & \multicolumn{1}{c|}{$\begin{array}{c}\text { TA } \\
\text { Reviews }\end{array}$} & \multicolumn{1}{c|}{\begin{tabular}{c} 
RAting \\
\hline Echinousa
\end{tabular}} \\
\hline Villa Maria & 98 & 5 \\
\hline Windmill & 98 & 5 \\
\hline Kimolis Hotel & 72 & 4.5 \\
\hline Kimolia Gi Studios & 51 & 4.5 \\
\hline Sofias Apartments & 35 & 4.5 \\
\hline Sardis Rooms & 27 & 4.5 \\
\hline Faros Studios & 18 & 4.5 \\
\hline Mikro Parisi & 12 & 4.5 \\
\hline Milaki & 11 & 4.5 \\
\hline Bonatsa Studios \& & 6 & 4.5 \\
Restaurant & & \\
\hline Meltemi Rooms & 21 & 4 \\
\hline Bonatsa Beach & 12 & 4 \\
House & & \\
\hline Maria Begni Studios & 1 & 4 \\
\hline
\end{tabular}


Source: Own creation.

\begin{tabular}{|l|r|r|}
\hline Opalio Apartments & 3 & 3.5 \\
\hline Giannis Studios & 6 & 2.5 \\
\hline Samplos Villas & 1 & 2 \\
\hline
\end{tabular}

Similarly, for the 34 restaurants, figure 4 displays the number of restaurants/bars versus five categories, namely email, webpage, Facebook, Instagram, and Trip Advisor. Again, as in Figure 1, Instagram is not that used.

Figure 4. Restaurants

Source: Own creation.

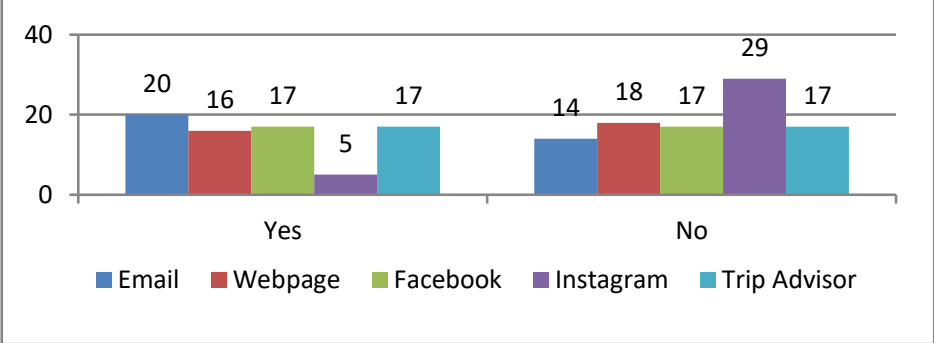

In figure 5, out of the 20 restaurants/bars with email addresses, six have a web mail, whereas 14 have a corporate associated with their registered email.

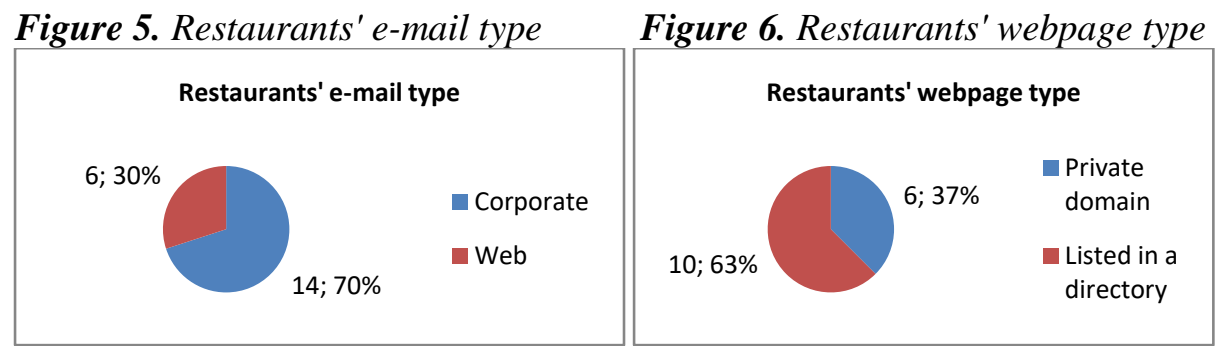

Source: Own creation.

Source: Own creation.

Results revealed that that few of the restaurants/bars have their own registered domain and more restaurants/bars use a tourist directory like gokimolos (Figure 6).

Out of the 17 Facebook pages, it appears that 17 have a "Likes" score, 8 pages have posted comments, and 11 pages have reviewed and an associated score. Almost all (14/17) have more than 300 likes each. It is also clear that reviewers are highly positive in their critique of the food quality and services. The average number of likes, in this case, is $\mathbf{5 7 8 . 4}$ and the standard deviation is 350 indicating a narrower spread than the hotels (Table 5).

Table 5. Restaurants/Bars Facebook pages

\begin{tabular}{|l|r|c|r|r|}
\hline \multicolumn{1}{|c|}{ Facebook Page } & FB Likes & FB Comments & FB Reviews & FB Rating \\
\hline StaventoCafe & 1021 & yes & & \\
\hline CycladesKimolosBohoris & 981 & & 27 & 4.9 \\
\hline
\end{tabular}


Mylona Ifigeneia, Amanatidis Dimitrios, Stavrianea Aikaterini,

Kamenidou Irene (Eirini), Mamalis Spyridon

\begin{tabular}{|l|r|r|r|r|}
\hline Agorakimolos & 957 & & 47 & 5 \\
\hline Stavento & 948 & & 57 & 4.9 \\
\hline Raventikimolos & 813 & & 32 & 57 \\
\hline CycladesKimolosPostali & 811 & & 16 & 4.9 \\
\hline Echinousa & 706 & yes & & \\
\hline Central-kimolos & 698 & yes & 24 & 5 \\
\hline sardis.kimolos & 697 & & 22 & 5 \\
\hline Bonatsa & 591 & & 6 & 4.9 \\
\hline meltemi.kimolos & 544 & & 7 & 5 \\
\hline Stoufragouli & 461 & Yes & & 5 \\
\hline PrezanisKonstantinos & 308 & Yes & & \\
\hline prasonisi.kimolos & 293 & Yes & & \\
\hline Brachera-Kimolos & 4 & & Yes & \\
\hline lostromos.kimolos & & Yes & & \\
\hline kyklades.kimolos & & & & 57 \\
\hline
\end{tabular}

Source: Own creation.

With respect to the use of Instagram, only five restaurants/bars have an Instagram account and although they have quite a few followers, they do not appear to post that much (Table 6).

Table 6. Restaurants/ Bars Instagram Accounts

\begin{tabular}{|l|r|r|r|}
\hline \multicolumn{1}{|c|}{ Name } & Posts & Followers & Following \\
\hline stavento_kimolos & 9 & 561 & 657 \\
\hline sardis_kimolos & 2 & 301 & 260 \\
\hline agorakimolos & 3 & 205 & 93 \\
\hline postali_kimolos & 6 & 177 & 2 \\
\hline kykladeskimolos & 1 & 140 & 200 \\
\hline
\end{tabular}

Source: Own creation.

Of the 17 properties in TripAdvisor, Kyma has received the most reviews and a rating of 4 . In fact, 14 restaurants/bars have a rating of 4.5 or 5, indicating a high percentage of satisfied consumers (Table 7) again.

Table 7. Restaurants/Bars appearing in TripAdvisor

\begin{tabular}{|l|r|r|}
\hline \multicolumn{1}{|c|}{ Name } & TA Reviews & TA Rating \\
\hline To Kyma & 171 & 4 \\
\hline I Kali Kardia "Bohoris" & 155 & 4.5 \\
\hline Sardis Café Restaurant & 100 & 4.5 \\
\hline Postali & 56 & 4.5 \\
\hline Stavento Ice Cream Parlour & 53 & 4.5 \\
\hline Meltemi - Restaurant & 51 & 4.5 \\
\hline Agora Cocktail Bar & 29 & 4.5 \\
\hline To Prasonisi & 27 & 4.5 \\
\hline Plagia Agora & 21 & 4.5 \\
\hline Perantzada & 20 & 4.5 \\
\hline To Raventi & 20 & 4.5 \\
\hline Bonatsa Restaurant & 16 & 5 \\
\hline Echinous & 16 & 4.5 \\
\hline To Panorama & 12 & 3 \\
\hline Kyklades Traditional Kafeneio & 10 & 4.5 \\
\hline
\end{tabular}


Nikos' Balcony

Stavento

10

Source: Own creation.

\section{Discussion - Conclusions}

In the past, social media have been perceived as a threat to traditional organizations' power (Shih, 2009). This can be attributed to the fact that organizations and corporations mainly controlled web 1.0 sites, while today, with the development of Web 2.0, we have shifted to a user-centric scenery. In 2020, business executives obviously found it hard to exclude them from their communication policy; on the opposite, they rather find it imperative to recruit them in promoting their businesses.

Our research's outcome is that local businesspeople in Kimolos have realized the potential of using the world wide web and social media for promoting their services; moreover, they have appreciated the significance of registering with a specialized platform, e.g., TripAdvisor, to reach out to their audiences. Social networks enable users to post and propose ideas about new services (Sigala, 2012), and this could be a motive for the local business executives to improve their services and therefore increase leveraging of social media.

Even though hotels overwhelmingly use email to communicate with tourists, restaurants, and bars do not depend on email and webpages; they mostly rely on Facebook. As Leung, Lee, and Law (2011) found, more than half of the studied hotels in Hong Kong still do not exploit this technology's potential. The situation seems to change even though the hotel owners are still hesitant to use new technologies.

Although Instagram is a promising social medium, in the case of Kimolos hotels and restaurants/bars, it has not been adopted that much. Instagram has been reported to excel as an effective communication and marketing tool to exhibit products with visual descriptions (Fatanti, 2015). Hopefully, shortly, the local authorities and business executives will increase the use of the medium. On the other hand, users can also use it as a promotion channel, as satisfied tourists can upload their own experiences from the island, effectively promoting it as a tourist destination. As Popova and Önder (2017) mention, a well-managed Instagram channel, with proper hashtag use and reposting of users' uploaded media, can achieve good reach and therefore has the potential of positively influencing the destination image.

In both accommodation and food sectors, one out of two businesspeople in Kimolos have registered their businesses in TripAdvisor, gaining positive reviews. Positive comments appearing in TripAdvisor refer to the quality of services and the beauties of the island, which obviously boosts tourists' attraction to Kimolos. As Crotts (2010) claims, a satisfied guest will probably revisit and make positive references to friends, relatives, and fellow bloggers. Social media can help local businesspeople to develop new ways of communication between them and the public. Social media have 
assumed a prominent place in the marketing and public relations equation (Mangold and Faulds, 2009).

Finally, we can see that even though the companies use social media, the municipality of Kimolos does not. As Bonson et al. (2015) state, municipalities need to use social media actively. On the other hand, the municipality has a very well-organized web page, and it is in their plans to engage in social media. Of course, volunteers use these tools in their effort to promote the beauties of the island.

\section{Limitations of the Study - Future Research}

The sample in a future study could include a larger number of informants, representative of the island enterprises who could probably be interviewed for a deeper analysis of their views. Future research would also benefit from extending to other regions of Greece to achieve comparative results. It would be interesting to compare the situation in Kimolos with other touristic destinations in Greece to develop best practices in using social media to promote tourist destinations via social media. Future research may further investigate the types of enterprises that use social media, for instance, whether enterprises in "famous" touristic destinations in Greece use social media more than enterprises in "less famous" places and destinations.

\section{References:}

Alhabash, S., Mundel, J., Hussain, S. 2017. Social Media Advertising: Unraveling the Mystery Box. In: Rodgers, S. and Thorson, E. (ed.) Digital Advertising: Theory and Research. London, Routledge.

Alghizzawi, M., Habes, M., Salloum, S.A. 2019. The Relationship Between Digital Media and Marketing Medical Tourism Destinations in Jordan: Facebook Perspective. In: International Conference on Advanced Intelligent Systems and Informatics. Springer, 438-448.

Belias, D., Velissariou, E., Kyriakou, D., Vasiliadis, L., Roditis, A., Varsanis, K., Koustelios, A. 2017. The differences on consumer behavior between mass tourism and sustainable tourism in Greece. Proceedings of the 5th international conference on contemporary marketing issues (ICCMI), Thessaloniki, Greece, 176-182.

Benoit, W.C., Holbert, L.R. 2008. Empirical Intersections in Communication Research: Replication, Multiple Quantitative Methods, and Bridging the QuantitativeQualitative Divide. Journal of Communication, 58, 615-628.

Bryman, A. 2004. Social science research methods. Oxford, Oxford University Press.

Buhalis, D., Law, R. 2008. Progress in information technology and tourism management: 20 years on and 10 years after the Internet - The state of eTourism research. Tourism Management, 29(4), 609-623.

Bodnar, K. 2010. The ultimate list: 300 + social media statistics. Available at: https://blog.hubspot.com/blog/tabid/6307/bid/5965/The-Ultimate-List-300Social-Media-Statistics.aspx?source $\% 20=$ Webbiquity.

Bonsón, E., Royo, S., Ratkai, M. 2015. Citizens' engagement on local governments' Facebook sites. An empirical analysis: The impact of different media and content types in Western Europe. Government Information Quarterly, 32(1), 52-62. 
Çelik, P., Yüzbaşıŏlu, N., Topsakal, Y. 2017. Destinasyon tanıtımı ve pazarlamasında sosyal medya: Home Turkey örneği. Journal of Human Sciences, 14(2), 10701081.

Chu, C., Luckanavanich, S. 2018. The Influence of Social Media Use and Travel Motivation on The Perceived Destination Image and Travel Intention to Taiwan of The Thai People. International Journal of Arts and Commerce, 7(3), 22-36.

Crotts, J.C., Mason, P.R., Davis, B. 2009. Measuring guest satisfaction and competitive position in the hospitality and tourism industry an application of stance-shift analysis to travel blog narratives. Journal of Travel Research, 48(2), 139-151.

Chatzigeorgiou, C., Christou, E. 2019. Social media in tourism marketing: Travellers' attitudes and encounters. In: Christou, E., Alexandris, K., Fotiadis, A. (Ed.): Tourman 2019 Conference Proceedings, Thessaloniki, Greece, 164-173.

Denzin, N., Lincoln, Y. 1998. The landscape of qualitative research, Thousand Oaks, CA: Sage Publishing.

Dickinger, A., Lalicic, L. 2015. An analysis of destination brand personality and emotions: a comparison study. Information Technology \& Tourism, 15(4), 317-340.

Hays, S., Pages J., Buhalis, D. 2013. Social Media as a Destination Marketing Tool: Its Use by National Tourism Organizations. Current Issues in Tourism, 16, 211-239.

Hassan, R. 2017. Leveraging social media in marketing Finland as a holiday destination to Spanish tourists. Thesis, Saimaa University of Applied Sciences Faculty of Business Administration Lappeenranta, Finland.

Huberman, B.A., Romero, D.M., Wu, F. 2008. Social networks that matter: Twitter under the microscope. First Monday, 14(1), 1-11.

Fatanti, M.N., Suyadnya, I.W. 2015. Beyond User Gaze: How Instagram Creates Tourism Destination Brand? Procedia - Social and Behavioral Sciences, 211, 1089-095.

John, F., Buhalis, D., Rossides, N. 2012. Social Media Use and Impact during the Holiday Travel Planning Process. In: Fuchs, M., Ricci, F., Cantoni, L. (Eds). Information and Communication Technologies in Tourism 2012, London, Springer.

Fragoulis, D, Chaniotakis, E, Stamatakis, M.G. 1997. Zeolitic tuffs of Kimolos island, Aegean Sea, Greece, and their industrial potential. Cement and Concrete Research, 27, 889-905.

Hanan, H., Putit, N. 2014. Express marketing of tourism destinations using Instagram in social media networking. In: Sumarjan et al. (eds) Hospitality and Tourism: Synergizing Creativity and Innovation in Research. Taylor \& Francis Group: London, UK.

Kaplan, A.M., Haenlein, M. 2010. Users of the World, Unite! The Challenges and Opportunities of Social Media. Business Horizons, 53(1), 59-68.

Karyotakis, M.A, Antonopoulos, N., Veglis, A., Kiorexidou, M. 2018. Tourists go home: Communication and Propaganda on YouTube. Proceedings of Communication Institute of Greece, $4^{\text {th }}$ International Conference on Communication and Management, Athens.

Kimolos, 2018. Retrieved from: https://www.kimolos.gr/.

Kim, S.E., Lee, K.Y., Shin, S.I., Yang, S.B. 2017. Effects of tourism information quality in social media on destination image formation: The case of Sina Weibo. Information \& Management, 54(6), 687-702

Leung, D., Lee, H.A., Law, R. 2011. Adopting Web 2.0 technologies on chain and independent hotel websites: A case study of hotels in Hong Kong. In: R. Law, M. Fuchs, F. Ricci (Eds.). Information and communication technologies in tourism, New York, Springer-Wien. 
Leung, D., Law, R., Van Hoof, H., Buhalis, D. 2013. Social media in tourism and hospitality: A literature review. Journal of Travel \& Tourism Marketing, 30(1-2), 3-22.

Miguéns, J., Baggio, R., Costa, C. 2008. Social media and tourism destinations: TripAdvisor case study. In: IASK ATR 2008. Advances in Tourism Research, Aveiro, Portugal, 26-28.

Mangold, W.G., Faulds, D.J. 2009. Social media: the new hybrid element of the promotion mix, Business Horizon, 52, 357-65.

Munar, A.M., Jacobsen, J.K.S. 2013. Trust and Involvement in Tourism Social Media and Web-Based Travel Information Sources. Scandinavian Journal of Hospitality and Tourism, 13(1), 1-19.

Munar, A.M., Jacobsen, J.K.S. 2014. Motivations for sharing tourism experiences through social media. Tourism Management, 43, 46-54.

Nixon, L., Popova, A., Önder, I. 2017. How Instagram influences visual destination image: A case study of Jordan and Costa Rica. In: ENTER 2017 eTourism conference, Rome, Italy.

Önder, I., Gunter, U., Gindl, S. 2019. Utilizing Facebook Statistics in Tourism Demand Modelling and Destination Marketing. Journal of Travel Research, 59(2), 195208.

Riffe, D., Lacy, S., Fico, F. 1998. Analyzing media messages. Using quantitative content analysis in research, London, Mahwah.

Seok, H., Joo, Y., Nam, Y. 2020. An Analysis of the Sustainable Tourism Value of Graffiti Tours through Social Media: Focusing on TripAdvisor Reviews of Graffiti Tours in Bogota. Colombia Sustainability, 12, 4426.

Shih, C. 2009. The Facebook era: Tapping online social networks to build better products, reach new audiences, and sell more stuff, Boston, MA, Prentice Hall.

Sigala, M. 2012. Social networks and customer involvement in new service development (NSD): the case of www.mystarbucksidea.com. International Journal of Contemporary Hospitality Management, 24(7), 966-990.

Stoldt, R., Wellman, M., Ekdale, B., Tully, M. 2019. Professionalizing and profiting: The rise of intermediaries in the social media influencer industry. Social Media + Society, 5(1), 1-11.

Thevenot, G. 2007. Blogging as a social media. Tourism and Hospitality Research, 7(3/4), 282-289.

Tom Dieck, M.C., Fountoulaki, P., Jung, T.H. 2018. Tourism Distribution Channels in European Island Destinations. International Journal of Contemporary Hospitality Management, 30(1), 326-342.

Xiang, Z., Gretzel, U. 2010. Role of social media in online travel information search. Tourism Management, 31(2), 179-188.

Ventouris, K. 2018. Interview with the mayor of Kimolos. Kimolos.

$\mathrm{Xu} \mathrm{Xu,} \mathrm{R.,} \mathrm{Pratt,} \mathrm{S.} \mathrm{2018.} \mathrm{Social} \mathrm{media} \mathrm{influencers} \mathrm{as} \mathrm{endorsers} \mathrm{to} \mathrm{promote} \mathrm{travel}$ destinations: An application of self-congruence theory to the Chinese Generation Y. Journal of Travel \& Tourism Marketing, 35(7), 958-972.

Wikipedia, 2018. Retrieved from: https://en.wikipedia.org/wiki/Kimolos.

Yoo, K.H., Gretzel, U. 2016. Use and Creation of Social Media by Travellers. In: Sigala, M., Christou, E., and Gretzel, U. (Eds), Social Media in Travel, Tourism and Hospitality: Theory, Practice and Cases. London, Routledge. 